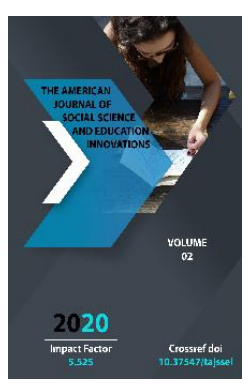

Journal Website: http://usajournalshub.c om/index,php/tajssei

Copyright: Original content from this work may be used under the terms of the creative commons attributes 4.0 licence.

\section{The Role Of The TV Anchor In The News Program And Authority He Has Achieved During His Career}

\author{
Yulduz Zahidova Qabilovna \\ Independent Researcher Of Uzbek State World Languages University, Teacher Of University \\ Of Journalism And Mass Communication Of Uzbekistan, Editor Of National \\ Teleradiocompany Of Uzbekistan
}

\title{
ABSTRACT
}

The scientific article is dedicated to professional and personality qualities of TV anchor. An attempt to analyzeprofessional responsibilities that allows to TV anchor to be successful in this type of activity in undertaken in this article. Especially, cited by the researchers all the main competencies, creativity, initiative, developed intuition, social adaptability, responsibility, ability to reflect, stress resistance, high standards of behavior, possession at a high level of verbal and non-verbal means of expression, the right motivational and target dominants, ideological maturity of the journalist.

In addition article stressed on basic factors of info programs broadcasting in developed countries. The article also pay attention to the activities of the leading local and foreign TV news. It is worth noting that the TV communicator has a great responsibility, as he has many requirements. TV anchor must constantly improve, lead the people, form the worldview of the audience. In the scientific article these aspects are stated. In addition, each state uses different methods to attract the attention of the audience, such as foreign TV anchors as speakers of news programs tend to broadcast. For this, there are actual examples. In particular, examples are given or the fact that TV anchor of American TV is elevated to the rank of a public figure. The article also identifies the components involved in the communication of TV anchor. These are components such as cognitive, affective, suggestive, conative.

The article shows the scientific and practical recommendations on the implementation of world experience and standards on the part of TV anchors of news program, thinking at the level of the speaker, the impact on viewers. 


\section{KEYWORDS}

TV anchor, broadcaster, journalist, information, news program, audience, viewer, television

\section{INTRODUCTION}

The article entitled "The role of the TV anchor in the news program and authority he has achieved during his career" is relevant not only for journalists, but also for those who work with the public. Because no matter what happens on any part of the world right now, human beings can immediately find out about it in different parts of the world. Television has a special role in informing our society and meeting the information needs of the population. Through the TV screen, each viewer will have the opportunity to hear the news or message, as well as see the process in it. It is an important task to convey information to the public in a memorable way, to form the worldview of the audience, to mobilize it to new heights. He is one of the leaders in this task, in achieving efficiency, in ensuring the level of visibility of the TV news program, in creating a whole integrity.

As the number of television news programs increases today, the task of creators is becoming more complex and they have to do research to attract as many viewers as possible to their program. In this case, one of the most responsible tasks is assigned to the host: he not only introduces the videos on the show, but also attracts the attention of the audience, subjective behavior in the frame, and then the events, news developments are displayed on the screen. Today's delicate, high-spirited audience longs to keep abreast of current events and global processes, so every quick, objective information, important innovation serves to increase not only the effectiveness, but also the prestige of the information program.

In many ways, the effectiveness of an information program is that the broadcaster chooses a relevant topic to appear on the screen, correctly identifies and expresses a social problem, speech culture, behavior in the frame, correct pronunciation of words and sentences, television image, ability to communicate effectively with the audience, communication skills, even depending on the dress code. The relevance of the scientific article is determined by the role and importance of the presenter in the information program, the impact on the audience, the formation of requirements for telecommunications and uniform professional standards, the need to improve the training of skilled broadcasters.

\section{MATERIALS AND METHODS}

Information programs in the system of the National Teleradiocompany of Uzbekistan operate in accordance with the principles of accuracy, speed and objectivity. These are the information and analytical programs "Akhborot 24" on "Uzbekistan 24", "NEWS 24", "New Period" (Yangi Davr) on "Yoshlar", 
"Tashkent 24" on "Tashkent" TV channel provides. Along with them, the information programs of existing non-governmental TV channels, such as "Central Studio" and "Time" (Zamon), also have a place in the information market. Each differs in its geographical coverage, variety of topics, form of ownership, direction, media, and the art of broadcasting by broadcasters. With its scale and essence, it covers not only the sociopolitical, economic and cultural life of the country, but also the events and happenings in the world. The main task of the creators of information programs is to take the initiative, to find interesting facts, events and problems in the life of our country.

Today, local television news programs are hosted not only by teachers who have passed dictation school, but also by broadcasters who read the finished text or write the text (eyeliner) themselves and have little experience. In these programs, journalists with journalistic skills turn to the films in a unique style, attracting the attention of the audience. There are those who convey the message using their acting skills, even if they don't write the text themselves. Of course, it is gratifying that young broadcasters in their ranks also conduct informational programs.

This indicates that the teacher-student tradition continues. Sensing the responsibility of young people on the air and skillfully conveying the news to the audience, following the advice of teachers, ensures an interesting presentation of information programs. Examples of such programs are Jamshid Umrzakov, Nodir Sobirov, Dilfuza Madaminova, Dilnoza Nishonbaeva, Arevat Grigoryan. Among them are nongovernmental TV channels - Jahongir Olimov, host of the information and analytical program "Time" (Zamon) of "Sevimli" TV channel, and Amirkhon Umarov and Sarvar Bahodirov, hosts of "Central Studio" program of "My5" TV channel. with the presentation of the novelty managed to catch the eye of the audience.

If we look at the history of Uzbekistan TV, previously only broadcasters who passed a number of competitions broadcast, they were given a probationary period. This test was the basis for the aspirations and hard work of such announcers as Galina Melnikova, Rano Djuraeva, Dilorom Umarova, Mirzohid Rakhimov, Abdumumin Utbosarov. According to Rano Juraeva, at that time the text was read live on the program "Akhborot" with a high level of responsibility. The commission, consisting of teachers such as Uktam Jobirov, Elbek Musaev, Ubay Burhon, paid special attention to the broadcast of the announcers, the text, the fluency of speech and the purity of dictation. Galina Melnikova, an honored cultural worker of Uzbekistan, said: "Many young people now read the finished text from a prompter. Frankly, I don't understand what he's saying. Because he doesn't pronounce words correctly, he doesn't even understand what he's reading. Personally, when I read the text myself, I felt each one from the bottom of my heart and thought mentally, not just emphasizing the voice. I answered for every word I said. I knew I was the last supervisor who wouldn't make a mistake if they gave me a text to read on Akhborot."

G. Nikulina, a television researcher, once described narration as "the main form of executive activity in the field of television." News reader was considered an intermediary in delivering the message because he read the finished text, but he did not have the opportunity to improvise. Although the announcers had previously played a certain role as an actor in front of the camera, they 
were embodied on the screen as a natural and sincere person. It is known that the National Television and Radio Company of Uzbekistan currently has almost no announcers. The ranks of speakers are declining. Instead, broadcasters will be able to broadcast. Telecommunications are proving their ability, mobility, independent and free operation, increasing the efficiency of telecommunications.

According to O.Nujdina, the TV presenter is becoming not only a source of information, but also a public figure who influences most people with his opinion and position. "A person who speaks in front of a wide audience has a huge responsibility: almost the whole country sees and hears him, and his words can have a strong impact on people's minds and opinions." But there is another idea: a broadcaster is an editorial staff member who, like everyone else, works with information, he or she should be an interviewer who tells the story, not who reads the news expressively.

The broadcaster is not actually a announcer or an actor, first and foremost, he or she is a partner in the process of preparing the news program. It is no exaggeration to say that he is a key member of the team, a player, like a producer, reporter or illustrator. The addressee, who is experienced and takes a responsible approach to his work, works closely with reporters and program creators.

Svetlana Sorokina, the host of Russia's Vesti news program, likens the on-screen TV to a stage model. She emphasizes that one of the key aspects to focus on in leadership is presenting the results of someone else's work.

G. Kuznetsov's article "Amplua semi gnomes" describes the broadcaster as follows: "The broadcaster appears on the screen every day with information that is vital for everyone. The audience knows that he is not the one who prepared the news, but he presents the film in such a way that the audience will see the process that took place today, the picture."

It is very important to understand and analyze the impact of the communicator on the audience from a scientific point of view. This idea is also supported by scientists (JLB. Matveeva, V.F. Petrenko, J. V. Karaganova, etc.) who have studied the formation of the image of the TV presenter on the screen in the field of mass communication.

N. Zvereva writes, "A professional broadcaster communicates with the audience in real time with calmness and confidence. <...> He conveys the message to the audience in such a way that it is easy and pleasant to hear."

V. G. Gorchakova described the host as a media product or an individual brand used in the implementation and development of the show.

In G. Kuznetsov's book "TV-journalist": "TVjournalist is an interesting profession. He will appear on TV and talk to the audience face to face,"he said. The personality of the initiator helps the viewer to comprehend facts and ideas. If during the show the audience discusses the strange hairstyle of the TV show or the ultra-modern costume or the way of behaving in the frame, then the expression of individuality creates an obstacle in communication."

V. Matveeva and I. In Smirnova's scientific works the peculiarities of the formation of the image of the presenter on the screen, the influence of television are studied. They found that a broadcaster's personal qualities influence the formation of another person's image. 
M. Andreeva, N.Shkoporov, T. Anikeeva, B. Lewis et al. focusing on the psychological significance of the TV presenter, the personal qualities that hinder the successful professional activity of the TV presenter, the difference in the mental specificity of the announcer and the initiator are explained.

Researchers, including Mark Parkinson, define the term "competence" differently depending on their approach. To summarize their views, this term refers to the successful implementation of professional responsibilities. At the same time, competence represents the meanings of knowledge, skill, ability. In our view, the competence of a broadcaster is understood as a set of professional, personal qualities and the ability to apply these qualities in practice, which is necessary for him to carry out his activities successfully and effectively.

Today, the profession of TV presenter is becoming a more complex and multifaceted profession. This professional is required not only to have talent, the ability to engage in creative activities, the ability to use words, but also to have a certain appearance and professional competencies. In American journalism, the word "talent" is used to refer to a TV presenter. Because the person who hosts the live broadcast is national pride, national wealth, national pride. This honor applies to national TV channels.

As the 21st century audience is very busy, it is worth appreciating that the audience is waiting for the show to air. Because the audience has the opportunity to watch and choose different TV channels. Waiting for the screen is a very rare event on TV. It must be understood, known, skillfully directed and used. The viewer expects an interesting conversation from the TV show, which is exactly the topic that interests him. Waiting for a meeting, which is why turning on the TV, constitutes the phenomenological essence of TV as a spectator dialogue.

TV anchor for the audience:

1) the appearance of the channel

2) creative person

3) embodied as a human being.

The parameters for waiting for the audience to appear on the opening screen are as follows:

1. The general image of the TV anchor, the audience recognizes him.

Here the broadcaster takes his place among the audience's constant communicators: family members, colleagues, neighbors, famous writers, artists, athletes. The spectator recognizes this or that contemporary, the interlocutors with whom he constantly communicates, that is, the broadcaster appears as a certain part of the intellectual life of each spectator. Intellectual life is directly related to this mental process. Man has such an innate character that he reluctantly imitates what he sees, especially when the appearance of programs and broadcasters broadcast on television has a direct effect on the mind of the spectator. That's why she wants to look like the broadcaster she likes in dressing up and talking.

The presenter is perceived as the "teacher" of the audience on the screen. For the modern man, the host of a television news program is a unique, distinct, unique force that connects him to the whole universe. This power motivates man to live in the face of all personal problems and global issues. The broadcaster has become a person in his circle in front of the audience, that is, an expression of trust, he performs not only the function of information, but also an integrative function uniting the audience. Also, the image on the 
TV screen serves to develop the consciousness of the audience, to raise their intelligence. Through his message, he instills a sense of belonging in the audience, increasing his political rights and knowledge. The broadcaster is portrayed in front of the audience as informing about new events, helping to understand and evaluate events. The audience is awakened by the news and comments on interesting issues and risky situations. The intellectual potential and skill of the broadcaster allows the audience to think freely.

2. The theme and direction of the TV anchor.

The audience is primarily interested in what topic the novice-journalist enters into the crowd.

- What topics should be covered in the program and why?

- What topics are not suitable for broadcasting?

- What are the most topical issues today?

- Which films should be broadcast live and which ones should be broadcast in advance?

- What topics require comment, opinion, analysis or discussion?

- How to update topics that have been covered for a long time?

- When should we stop covering these topics?

- What do the information programs of competing TV channels do to find answers to the following questions?

The TV presenter, who is looking for answers to these questions, has his own direction. Because he works based on questions about what the audience is interested in, what issues are on his mind, what topics he wants to see in the films, and he always lives with the pain of the audience. As the addressee introduces the viewer to the world of information, it creates the need to focus on events and happenings in terms of their direction. The information leader not only reads the black letters on the white paper, but also teaches the viewer to take a sharp look at the details of a particular event. Not only through video sequence-based footage, but the presenter himself evokes the feeling of an event participant in the viewer with a real "animation" of the messages. It is these aspects that encourage you to see the news and news program.

\section{The periodicity of the TV anchor appearing on the screen.}

It should be aired continuously, if it does not appear on the screen for a long time, it will be forgotten by the audience. Life does not stop there. "Television is not an art that lasts a lifetime. If the presenter doesn't air for half a year, no one will remember him, "said Peter Tolstoy, the host of Russia's Channel 1 television.

Researcher N. Golyadkin, on the other hand, said that while the long-term performance of a television show is highly valued, its absence from the screen is tantamount to being left out of the audience's view. The audience perceives him as a family member in a figurative sense because he sees some of the broadcasters a lot on screen. They carefully follow every detail in their creative and personal biographies. There are also broadcasters who have not been on the air for a long time, even years later, and the audience still remembers them. But it can be the opposite, and it will be more so. 
4. Impress as a creative employee in a TV anchor audience.

Some are portrayed as leading politicians (Quddus Azam), others as political commentators (Kobilbek Karimbekov), others as international events, others as sports commentators (Davron Fayziev), and still others as news presenters (Jamshid Umrzakov).

In modern television, it is observed that the "broadcaster-viewer" relationship prevails over the "information-viewer". The connection between the emotional-spiritual and purely informational layers of the presented message can be considered as "special information about the presenter himself in the process of trying to communicate personally with the audience." V. According to Matizen, this type of communication serves to make the presenter popular: for the viewer, the familiar face in the frame is first and foremost the main participant of the show, and each time it appears on the air, it becomes interesting information for the audience.

\section{Starting screen image in the audience, screen symbol.}

It is natural to impress him as a professional. The audience waits for him, knowing that this broadcaster will appear on the screen. In this case, the professional screen qualities, the ability to behave on the screen play a special role. These are appearance, agility, ability to act according to the situation, free adaptation to the topic, understanding of the audience. These parameters shape the broadcaster in the mind of the viewer as a truly reputable person, just like a screen professional.
6. Impressions of the audience from the leading personality, human qualities.

That is, it evokes a sense of confidence in the audience, pleasantness, passion, warmth, initiative, the desire of the audience to communicate with the broadcaster from the outside, the warm impression of communication. According to Christian Amanpour, one of America's leading international television journalists, "The reason people trust me is because they see a journalist in front of them who takes his job seriously and, most importantly, knows what he wants. All the preparation for my strong desire, confidence, effort, and purpose to reach me seemed strange even to those around me. I would do great things, not small things, and I would do my best for everything. "

Today, the distinctive features of television can be described by the large number of TV channels, the use of different methods of television communication, the diversity of genres in television, the possibility of creative implementation of various TV projects. But in most cases, the success of the show is determined by the charm, charm, intelligence and thinking of the presenter. The phenomenal power of television exposure is evident in the following factors:

- Color image, picture

- Brightness of the audiovisual series

- Communicative capabilities of the TV anchor.

- The profession of TV presenter, like any other profession, requires certain professional competencies (from the Latin - to be relevant). Without them, work efficiency cannot be achieved. Competence includes: - business qualities;

- Personal qualities;

- Knowledge and skills.

- Researcher Irina Pavlovna Smirnova cites the main competencies of the TV anchor: 
- Professionalism;

- Communicativeness;

- Creativity;

- Initiative;

- Advanced intuition;

- Social flexibility;

- Responsibility;

- Resistance to emotional shocks;

- High standards of behavior;

- High level of knowledge of verbal and nonverbal means of expression;

- Clearly targeted dominants;

- The breadth of the journalist's worldview.

L.V. Based on the results of Matveeva's research, it can be said that the qualities necessary for the image of an "ideal" broadcaster include self-confidence, communication and sincerity.

It should be noted that communication with the public is the art of conveying news that happens in an instant. Having mastered this art, TV presenters with the above-mentioned professional competencies are now able to host a news program. How skillfully they perform this task can be seen from the viewer's assessment, which news program they prefer to watch, which broadcaster they prefer to see. So, if this artist loves his profession, works hard, tries hard to cover the topic in an interesting way, if his speech is fluent, he will succeed. As long as he is tasked with addressing millions of people as a speaker, he should feel this responsibility deeply. If a highly qualified, experienced speaker leads a parliament, he or she should lead the inaugural program with high skill as the director of that show.

According to the book "Society in Journalism: Secrets of Mastery", the presenter with his professional level ensures the audience of the show.

The news program of each TV channel in the system of the National Television and Radio Company of Uzbekistan operates in its own direction and style. For example, the program "Akhborot 24" will cover the current events in the country and the world, the ongoing reforms in our country, the visit of the President of our country to foreign countries, as well as state and government decisions, presidential decrees. It is noteworthy that this program is broadcast live more than other informational shows, and in them we can see a new look - new broadcasters.

It should be noted that the host of a live broadcast will present his identity directly in front of millions of viewers, and indirectly in a pre-recorded show. Journalism allows him to independently convey television news to the audience in a comprehensible and expressive way.

As we follow the news programs of different developed countries, each has its own direction. Euronews broadcasts events, processes and changes that take place without initiators. Saudi Arabia's television news programs are unimaginable without beautiful broadcasters. Great attention is paid to their image and appearance. Broadcasters can also be compared to the beauties of the world. In Russia, too, professional, experienced broadcasters are used to host TV news programs. We even see female and male presenters in 2 tandems leading these shows with various sarcastic expressions, sarcasm and sarcasm, explaining the true nature of the events. In the U.S., not so much attention is paid to the beauty of broadcasters, innovation comes first. Experts from this state, scientists with extensive experience in the field of 
television, point out that the research profession is gradually disappearing altogether.

It is no secret that since 2012, information shows have been conducted by robotic broadcasters as well. These robots read the text without error, in a different tone, and with natural hand gestures, but there is one aspect that these humanoid robots convey the message to the public without any emotion.

China is not far behind the country in this regard. At the Xinhua News Agency, the robot-host reads the news in English and the state language. It keeps the viewer informed of the latest news happening day and night anywhere in the world. The purpose of creating a robot is to save money for broadcasters and developers, to deliver messages faster, increase resource efficiency and add originality to the show. The robot was not well received by the audience. People have complained about the artificiality of the robot's facial movements and voice.

It is clear that each country is using different ways to attract the attention of the audience, and foreign presenters are trying to broadcast as the speaker of the news program. It is worth noting that in 1982 he was recognized as a leading public figure on American TV. At the time, President Ronald Reagan was acknowledging the host's skill by watching a news program on CBS (CBS). After the broadcast, he called the host, Dan Razer, to deliver a message that he conveyed to the public on screen and boldly expressed his attitude to him, specifically to discuss the decision to cut arms shipments to Taiwan. There are also journalists and pioneers in Uzbekistan who have a sharp pen and deep observation, but they are few. One of them is
Farhod Mahmudov. This professional journalist, who skillfully covers the visits of the President and internationally covers the reforms being carried out by the head of our state, is currently working as a state adviser to the President.

The main job of a TV presenter is to communicate between people. There are specific features of telecommunications that a broadcaster who understands it will increase the efficiency of his business.

There are 4 components in telecommunication communication. These are:

cognitive (lat. cognition - knowledge) consciousness, thinking. Cognitive influence is the transmission of a message that is received by the mind.

affective (lat. affectus - mental excitement) associated with emotion, mood, experience. Communication participants share emotional experiences with each other.

suggestive (lat. suggestio - to influence) - to influence the mind. It is about influencing the human psyche.

conative (lat. conatus - attempt, aspiration) associated with the aspiration to a certain behavior. Message delivery plays an important role in the news program. It tries to give the starting feeling in entertainment programs and talk shows.

Many viewers feel the norms of one of the components in this or that TV product with an inner feeling. Let's say that if a TV newscaster overreacts to his or her feelings, he or she will embarrass and irritate the viewer. It is important to remember that news is not a place to show personal attitude. The professionalism of the presenter is assessed on the effectiveness of speech communication. The effectiveness of telecommunications depends on how 
accurately the broadcaster imagines his or her audience, knowing their interests. The process of communication and a sense of shared goodwill is more important to the audience than information. The TV presenter, who has the ability to provide mental comfort, is perceived by viewers as their family members due to deep identification.

The host is also a broadcaster, actor, and interlocutor. He creates a personalized image on the screen, that is, he rediscovers himself. Telecommunication occurs when the product of the communicator's speech activity becomes the object of active perception of the recipient (audience). In the process of perceiving the text in terms of meaning, the TV presenter and the viewer form a communicative system. In front of the camera, the broadcaster addresses the viewer in the form of a monologue. However, communication and audience trust can only be achieved if this monologue becomes a dialogue.

Khurshid Dostmuhammad says about the tasks of a journalist: "As a journalist always works among people, he first of all needs to study the psychology of people in depth. The art of working with people, being able to relate to them, and ultimately influencing a very wide audience, the sense of responsibility shows the need to pay special and serious attention to the psychology of our profession".

In fact, the responsibility of the broadcaster, the demands placed on him are enormous. He must always be able to search, to follow the people, to encourage them to observe correctly, to serve to shape the worldview of the audience. Because the word of the initiator will resonate. What he said today, what he conveyed, will be heard tomorrow and the public will speak his language. The creativity of a broadcaster who seeks to create news, searches, and makes the program interesting will not go unnoticed.

\section{CONCLUSION}

Television and every TV show is a complex system. Modern news television places great emphasis on the universality of information. This is due to the emergence of new trends in information, the relationship between the addressee and the addressee, and a radical change in performance on television. In television practice, a style of personalization of innovation has emerged, as a result of which the viewer's attitude to television has changed for the better. It is necessary to create a quality information program, to know the possibilities of creating a work schedule for the audience to look forward to the opening screen, to prepare videos that meet the requirements, to choose the right host, to strengthen its place and position in the program. There is no doubt that the combination of these components will bring success to the TV channel.

The effectiveness of a TV presenter's activity depends not on his level of popularity and popularity among the people, but on how many audiences his show attracts and how much it reaches the audience. Here, the language of the television, the image on the screen, the skills of communication, the style of broadcasting, the etiquette of the screen and other important aspects of its activities are the decisive factors.

Examining many empirical sources, we can conclude that to overcome the initial communicative barriers to increase the effectiveness of communication with the audience, develop methods of communication, knowledge of communication 
techniques, study the interests of the audience, improve text quality, rich and fluent speech, must be able to express clearly. Unfortunately, in some news programs, the editors write in the style of a newspaper, some communicators read a dry text on the world stage, let alone in our country, without understanding the essence of the reforms.

Some of the initiators of the information program lack basic journalistic knowledge (skills of working with text, the ability to find interesting topics and adapt them to the needs of the audience and communication) and professional competencies. This is due to the fact that those who do not have higher education are given the opportunity to broadcast, because they do not know the secrets of the industry and professional ethics. Therefore, in order to further revitalize the information program, it would be expedient to follow the following suggestions and recommendations that will serve the development of start-up activities:

- The main numbers of information programs are conducted by regular presenters;

- $\quad$ specialization of broadcasters;

- preservation of the addressee's own image;

- Improving the quality of direct communication in all news programs and, for this, strengthening the professional skills of broadcasters and journalists;

- pay close attention to every aspect of the broadcasting of television news programs;

- the pronunciation of the communicator meets the requirements of literary language norms;

- make effective use of the experience of broadcasters and journalists, researchers and competitors and apply it in their work;
- A professionally designed information program should contribute to the wellbeing of people using a means of influencing the audience.

In our view, general theoretical conclusions and suggestions may be of interest to practicing journalists.

\section{REFERENCES}

1. Allaberganova S. Galina Melnikova: "Aqliy kamolotga erishgan odam kamtar bo'ladi" ("A man who has achieved a reasonable perfection will be humble") / / 16.12.2017 http://darakchi.uz/uz/40002 date of application: 03.02.2020.

2. Brodzka A. Efirnie stress Svetlani Sorokinoy( Air passions of Svetlana Sorokina)

https://www.google.ru/amp/s/www.w omanhit.ru/amp/leisure/tv/2-17-09-27-

efirnie-strasti-svetlany-sorokinoj/ date of application: 05.10.2018.

3. Galina $M$. Obshenie $v$ jurnalistike: sekreti masterstva(Communication in the journalism: secrets of mastery), St.Petersburg.: Peter Press, 2008. $217 \mathrm{p}$.

4. Gorchakova V.G. Brendami ne rojdayutsya (Brands are not born)/ / Telesentr. - 2008. - № 3 .

5. Dedov A. Texnologii televizionnoy jurnalistiki. Uchebnoe posobiye.(Technology of television jotnalism. Scientific manual.) Curgan State University, 2017. - 200 p.

6. Do'stmuhammad H. Jurnalistning kasb odobi muammolari: nazariymetodologik tahlil. Monografiya, (Problems profession courteousness of journalist: theory-methodology 
analyze), Monograph,Tashkent:Generation of new century, 2007. $200 \mathrm{p}$.

7. Zvereva N. Shkola regionalnogo telejurnalista (School of regional TV journalist). - M.: "Aspect-Press", 2004. - - $320 \mathrm{p}$.

8. Kazakova L. P. Psihologiya massovih kommunikatsiy(Psychology of mass communications). - Moscow: Moscow State University by Ivana Fyodorova, 2014. - $112 \mathrm{p}$.

9. Karaganova J. V. Ekranniy obraz televizionnogo jurnalista (Screen image of a TV journalist): dis. ... kand.filol.nauk: 10.01.10 / C.V.Karaganova. - M., 2005. .-156 p.

10. Kuznetsov G. Amplua semi gnomov(Role of the seven dwarfs) / / journalist, № 7.1993.

11. Kuznetsov G. Tak rabotayut jurnalisti TV(This is how TV journalists work). M.: Publishing house of Moscow University, 2004. .-400 p.

12. Lebedev A. N., Bokovikov A. K. Eksperimentalnaya psihologiya $\mathrm{v}$ rossiyskoy reklame(Experimental psychology in Russian advertising).Moscow: Academy, 1995. — 144 p.

13. Lenin A. $\vee$ Yaponii poyavilsya robotvedutshiy novostey (In Japan, a robot news anchor has appeared) / / 25.06.2014

https://www.google.ru/amp/s/rg.ru/am p2014/06/25/robot-site-anons.html date of application: 07.03.2020

14. Matveeva L.V., Anikeeva T.YA., Mochalova YU.V. Psihologiya televizionnoy

kommunikatsii(Psychology in television communication).Moscow: RIP-holding, 2004.-316 p.

15. Interview of the author with TV anchor Ra'no Djuraeva. March 1, 2020.
16. Nikulina G. Litsa znakomie i neznakomie: zametki o televizionnom portrete(Faces familiar and unfamiliar: notes on a television portrait).- M.: "Art", 1980. .-142 p.

17. Nujdina A. Imidj televedushego: setevoy jurnal( Image of TV anchor) 2010. [Elektronniy resurs]. http://www.evartist.narod.ru/text9/22. htm\#\%Do\%B7_05 date of application: 03.12.2016.

18. Robot-diktor chitaet novosti na kitayskom TV(The robot-TV anchor read news on Chinese TV / / 10.11.2018 https://www.if24.ru/robot-diktorchitaet-novosti-na-kitayskom-tv/ date of application: 07.03.2020.

19. Smirnova I.P. Klyuchevie kompetencii televedushego: ot talanta $\mathrm{k}$ professionalizmu (Key competences of TV anchor: from talent to professionalism)//Journalism and media education - 2008. Proceedings of the III International scientific and practical conference. - Belgorod: Belgorod State University, 2008. - 111 p.

20. Televizionnaya jurnalistika. Uchebnik (Television journalism. Manual) / Pod red. A.Ya.Yurovskogo. - M.: Publishing house of MSU, 1994. - $237 \mathrm{p}$. 